\title{
The Greek Orthodox Patriarchate of Istanbul and the Heybeliada Theological School (Halki Seminary): History, Discussions and JDP Government's Policy
}

\author{
Outkou Kirli Ntokme *
}

\begin{abstract}
In countries like Turkey, issues such as minority rights/freedoms and religious rights/freedoms are generally considered painful topics of domestic and foreign policy mainly because there is usually a general belief that such issues are "imposed" by external actors like the EU and the United States.

The Greek Orthodox Patriarchate of Istanbul and Heybeliada Theological School (Halki Seminary), have been targets of the nationalist and/or conservative religious media for a long time. Additionally, the traditional widespread acceptance of these institutions as Turkish by the successive Turkish governments, and the perception of the issue within the framework of "reciprocity" between Turkey and Greece, made these issues "chronic" topics of Turkish domestic and foreign policy. However, it is difficult to say that Turkish public opinion as a whole share the same view on this issue. Especially since 2002, the Justice and Development Party government, created hopes and expectations that actual steps would be taken towards the problematic title of "ecumenical" of the Patriarchate and the reopening of Heybeliada Theological School. Yet, the JDP government like its predecessors, does not recognize the ecumenicity of the Patriarchate and continues to point out the reciprocity understanding regarding the opening of the Theological School.
\end{abstract}

\section{Keywords}

Greek Orthodox Patriarchate, "Ecumenical", Heybeliada Theological School, Halki Seminary, JDP Policies.

* Outkou Kirli Ntokme is a PhD candidate in International Relations, Ankara University, Ankara, Turkey. 


\section{Introduction}

The end of the Cold War marked changes on the agendas of all countries and issues such as human rights, minority rights and religious rights and freedoms which were being discussed loudly since 1970s, gained a new momentum. In Turkey for long years, these topics were mainly regarded "taboo" topics of internal and foreign politics. For example, since the establishment of the Turkish Republic, the Greek Orthodox Patriarchate of Istanbul

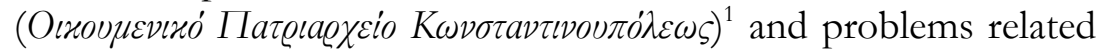
with it (especially the usage of the "ecumenical title" of the Patriarchate), are considered domestic issues since this institution has been considered solely as a "Turkish institution". However, despite Turkey's policy to approach them as "Turkish" institutions and therefore considering them part of its domestic agenda and Turkish law, they have international aspects.

In Turkey, the debates regarding the Greek Orthodox Patriarchate and the Heybeliada Theological School (or Halki

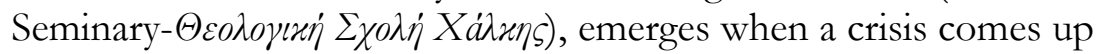
concerning the Greek Minority of Istanbul or the Turkish Minority

1 Today the Greek Orthodox Patriarchate of Istanbul, includes the

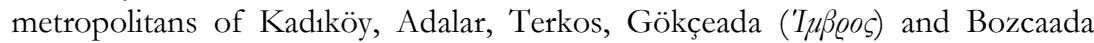

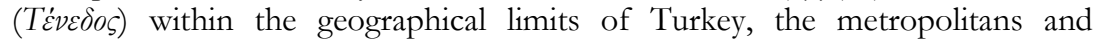
archbishops residing in Crete $(K \varrho \dot{\tau} \tau \eta)$ and on the Dodecanese $(\Delta \omega \delta \varepsilon x \dot{a} \nu \eta \sigma a)$ in Greece, which includes the metropolitans of Eastern Aegean Islands (Níoor Avazoגıxoú A annexed to Greece in 1912, and various monasteries and religious centers

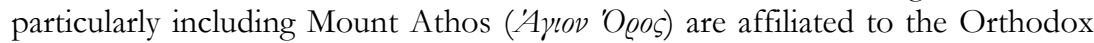
Greek Patriarchate in Istanbul. Moreover, several spiritual regions such as the American Archbishopric, the Australian Archbishopric, metropolitans in Europe, and the New Zealand Archbishopric are under the jurisdiction of the Patriarchate. See The Ecumenical Patriarchate of Constantinople <http://wnw.patriarchate.org/>, (access date: 25 November 2009). In Turkey is usually referred as Phanar Greek Patriarchate (Fener Rum Patrikhanesi), because its "ecumenical" status is not recognized. The word "ecumenical" comes from the Greek word oxoupicu meaning the total of all people living all over the world. In this paper it will be referred as Greek Orthodox Patriarchate because the issue of ecumenisty it a subject of Christian teaching. 
of Western Thrace between Turkey and Greece or even when the Orthodox Greek Patriarch gives an interview and makes a public statement. ${ }^{2}$ Thus they have become a matter of "reciprocity" between Turkey and Greece.

Russia's position on this issue adds another element to the international dimension. The end of the Cold War and the dissolution of the Soviet Union turned the attention of Russia once again towards the Orthodox Church and Orthodox world which was in a way neglected during the Communist era. At the beginning of 1990s the Russian Orthodox Church by questioning and by challenging the "ecumenical" status ${ }^{3}$ of the Greek Orthodox Patriarchate of Istanbul due to the demise of the Greek Orthodox population living in Istanbul, turned the attention of the United States to this institution as in the first years of the Cold War.

The end of the Cold War required Turkey to reconsider its policies regarding these "taboo" issues. This rethinking and reconsideration is partly connected with Turkey's efforts to join the European Union (EU), which has become a major aim of Turkish foreign policy again since the 1990s. In addition to reconsider the taboo issues, EU's pressure on Turkey to reopen the Heybeliada Theological School and to recognize the "ecumenical" status of the Patriarchate by including these issues in progress reports ${ }^{4}$ whenever possible, even though it is not a direct

2 Patriarch Vartholomeos I at a TV program on US Channel CBS said that "he feels 'crucified' living in Turkey under a government he says would like to see his Patriarchate die out". For the details of Patriarch's TV interview see "The Patriarch Bartholomew", 60 Minutes, 20 December 2009, <http:/ / wnw.cbsnews.com/video/watch/?id $=6001717 n>$, (access date: 28 December 2009).

${ }^{3}$ Melek Fırat, “1945-1960 Yunanistan'la İlişkiler”, Baskın Oran (ed.), Türk Dıs Politikası Kurtuluş Savaşından Bugüne Olgular, Belgeler, Yorumlar, Vol. I, İstanbul, İletişim Yayınları, 2001, p. 584.

4 Please see, Turkey Progress Report 2009, Commission of the European Communities, Brussels, 14 October 2009, p. 22,

<https:// wnw.mfa.gov.tr/data/AB/2009_Ilerleme_Raporu_Ingilizce.pdf>, $\quad$ (access date: 24 August 2010). 
condition for EU membership; has transferred these topics inevitably on international level once again.

The reconsideration of policies on the demands of the ecumenical status of the Patriarchate and reopening of Heybeliada Theological School have also been a topic of Turkish-American relations. ${ }^{5}$ Since the 1990s the comments and "kind" requests by US Presidents ${ }^{6}$ from Turkey regarding the reopening of Heybeliada Theological School and solution of the problems of the Greek Orthodox Patriarchate gained momentum. More recently US President Obama's reference to the matters at his speech in the Turkish Grand National Assembly ${ }^{7}$ and during the meeting with the Turkish President Recep Tayyip Erdoğan at Washington on 7 December ${ }^{8}$, demonstrates the international aspect of these issues.

When Justice and Development Party-JDP (Adalet ve Kalkinma Partisi-AKP) took office on 3 November 2002, there was an international and domestic optimism about the solution of these problems because it was a pro-Islamist single party government and appeared to be sensitive on issues such as religious rights and freedoms. Additionally, there have been expectations whether the government's "Democratic Opening" 9

5 Firat, “1945-1960...”, pp. 584-587; Çă̆r1 Erhan, “1960-1980 ABD ve NATO’yla İlişkiler”, Baskın Oran (ed.), Türk Dış Politikeası Kurtuluş Savaşından Bugüne Olgular, Belgeler, Yorumlar, Vol. I, İstanbul, İletişim Yayınları, 2001, p. 704.

${ }^{6}$ In a letter sent to Prime Minister Tansu Çiller in March 1994, US President Bill Clinton requested that the Patriarch be relieved of its distressful predicament, see Elçin Macar, Cumburiyet Döneminde İstanbul Rum Patrikhanesi, $2^{\text {nd }}$ ed., İstanbul, İletişim Yayınları, 2004, p. 241.

7 The White House Office of the Press Secretary, Remarks by President Obama to the Turkish Parliament, 06 April 2009,

<http:/ / wnw.whitehouse.gov/the_press_office/Remarks-By-President-Obama-To-The-

Turkish-Parliament>, (access date: 15 August 2010).

8 The White House Office of the Press Secretary, Remarks by President Obama and Prime Minister Erdogan of Turkey after meeting, 07 December 2009, < bttp:/ / www.whitehouse.gov/ the-press-office/ remarks-president-obama-and-prime-ministererdogan-turkey-after-meeting>, (access date: 15 August 2010).

9 For details see Sorular ve cevaplaryla Demokratik. Açllım Süreci Milli Birlik ve Kardeşlik Projesi, AK Parti Tanıtım ve Medya Başkanlı̆̆ı, January 2010, p. 14, 
would bring a change in the traditional state policy and would include the Greek Orthodox Patriarchate and the Heybeliada Theological School, in short whether the government could make a radical shift in decoupling these issues from the long established policy of "reciprocity".

The purpose of this paper is to give some historical background about the Greek Orthodox Patriarchate of İstanbul and the Heybeliada Theological School in order to understand better the discussions upon these issues among Turkish intellectuals, researchers, academicians and finally to question whether the current Turkish government's policies and attitudes especially upon the usage of the "ecumenical" title of the Patriarchate and the demands of reopening the Heybeliada Theological School have changed or not.

\section{Historical Background: The Greek Orthodox Patriarchate of Istanbul and Heybeliada Theological School}

\section{The Greek Orthodox Patriarchate of Istanbul}

It is believed that the first church in Istanbul (Byzantium) was founded in 37 A.D. by St. Andreas (Apostle Andrew, the firstcalled Apostle of Jesus). When the emperor Constantine the Great declared Constantinople (Istanbul) as the new capital of the empire in 330 A.D., the name of the ancient city was changed to "New Rome" and the Church became the Church of the Byzantine Empire. Its position and prestige was formally upgraded in the year 451 A. D., when the Holy Synod, the most important governing body of this organization, named the Church as a

<http:/ / www.demokratikacilimkitabi.com/demokratik_acilim_kitabi.pdf>, (access date: 15 February 2010). 
Patriarchate and by the end of the $6^{\text {th }}$ century the Patriarch had obtained the title of being an "ecumenical" leader. ${ }^{10}$

After the conquest of Istanbul by the Ottomans in 1453, Sultan Mehmet the Conqueror issued an imperial edict ${ }^{11}$ recognizing some privileges to the Greek Orthodox Patriarchate. Also by this imperial edict the Sultan recognized the Patriarch Gennadios Scholarios as milletbassı-religious leader of the Orthodox people. During the Byzantine Empire period, Byzantine emperors limited the authority of the Patriarch only to religious affairs and prevented them from getting involved in secular affairs, thus the power of the Patriarch was in a way only limited to religious issues. However, in the Ottoman era as part of the millet system and together with the imperial edict issued by the Sultan, the Greek Orthodox Patriarch was a both a religious and political leader. The Patriarch also ensured the coordination of Orthodox churches within the Ottoman Empire. ${ }^{12}$

${ }_{10}$ Macar, Cumburiyet Döneminde..., p. 29. The Patriarchate, whose influence and jurisdiction increased in the following centuries particularly over the Eastern world, started to have conflicts with the Papacy. In the beginning, these conflicts grew out of disagreements over who would have the power to control the regions where Christianity spread and at the $7^{\text {th }}$ ecumenical council which was held in 787 A.D., the two churches excommunicated each other. Conflicts between the two Churches were not limited to disagreements over authority. They also arose in relation the Christian doctrine and the two churches were

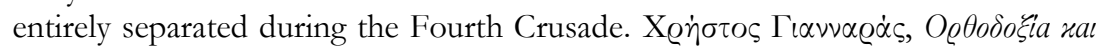

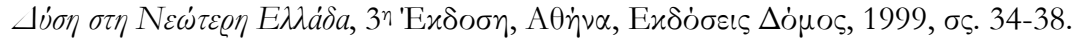

11 The religious, political and administrative rights and competences were modified through the history of the Ottoman Empire and were later brought together by Sultan Abdülmecit I in the Imperial Reform Edict of 1856, Macar, Cumburiyet Döneminde..., pp. 38-61.

12 The millet system was not founded according to ethnic relations, but according to religion and religious sect. Serbians, Bulgarians, Orthodox Albanians and Orthodox Arabs, together with Hellenic society as a whole, were therefore subject to the Greek Orthodox Patriarchate which was the head of the Greek Nation. For details regarding the privileges of the Greek Orthodox Patriarchate under Ottoman rule see D. A. Zakythinos, The Making of Modern Greece From Byzantium to Independence, Totowa, New Jersey, Rowman and Littlefield, 1976, pp. 43-55; Steven Runciman, The Great Church in Captivity, Cambridge, Cambridge University Press, 1968, p. 165; Apostolos E. Vacalopoulos, The Greek Nation 
As the Ottoman Empire grew in size, the range of influence of the Patriarch also expanded accordingly. But when the Empire began to decline and loose territory, Orthodox churches affiliated to the Greek Orthodox Patriarchate began to be detached in order to become independent national churches. This process began during the 19th century when many new states were founded in the Balkans because of the spread of nationalism in the region. Almost every new state with a majority Orthodox population founded its own national church. As a result, the power of the Greek Orthodox Patriarchate declined. Thus it can be said that the Patriarchate has strengthened along with the Ottoman state, and thus it weakened in parallel to the decline of the state. For example, the Greek Orthodox Patriarchate was seriously affected by the declaration of independence of the Balkan nations, particularly of the Greek.

In 1821 when the Greek insurrection began in the Pelopennese peninsula, which led to the Greek independence in 1830, the Patriarch Grigorios V excommunicated those that supported the insurrection. However, his denunciation was far from satisfying the Sultan since he had full responsibility for his people, eventually he was executed. Furthermore, the Church of

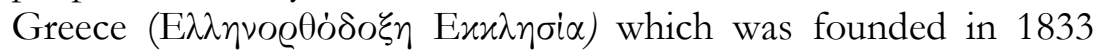
declared "unilaterally" autocephalous without the approval of the Greek Orthodox Patriarchate of Istanbul. ${ }^{13}$ Even though, the

1453-1669, trans. Ian and Phania Moles, New Jersey, Rutgers University Press, 1976, pp. $100-150$.

13 According to Kitromilidis this action of the Church of Greece defines a basic difference among two institutions. The Church of Greece, contrary to the Greek Orthodox Patriarchate, during the $19^{\text {th }}$ and $20^{\text {th }}$ centuries became more interested with political issues and played an important role at the development of the Greek nationalism and formal state ideology. See $\Pi \alpha \sigma \chi \dot{\alpha} \lambda \eta s$

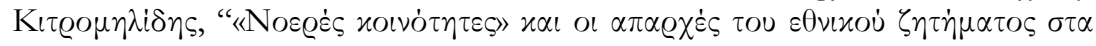

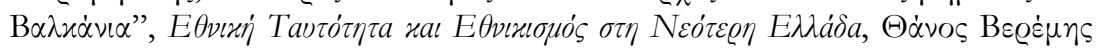

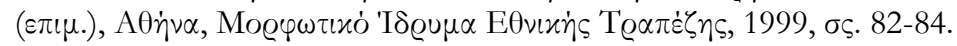


Greek Orthodox Patriarchate continues to hold its primus inter pares (first among equals) position in the Orthodox world. ${ }^{14}$

During the World War I and the ensuing Turkish Independence War (1919-1922), the Patriarchate was observed to have been intensely involved in political activities against the Ottoman Government. ${ }^{15}$ This negative image of the Greek Orthodox Patriarchate even today exists in Turkey and therefore it is still perceived as a source of "dissension" from a wide range of the Turkish population.

The significance of the Lausanne Peace Treaty ${ }^{16}$ for Turkey is that it is the founding treaty of the modern secular Turkish Republic and its international recognition. The modern Republic of Turkey represents a break with its Ottoman past after its foundation. In 1922, Turkish National Assembly abolished the sultanate and later, in 1924 abolished the Caliphate making a radical transition into a republican experiment. All religious institutions were shut down and every religious community was forced to dissolve as a sign of eliminating any religious interference into political sphere and transforming Turkey into a secular nation. Despite the Turkish state's attempts were mainly focused on eradicating ties with Islamic state tradition, institutions of other religions were also subject to this policy. Secularism has been a very crucial aspect of Turkish politics and even today it is an integral part of the state.

During the Peace negotiations at the Lausanne Peace Conference, the Turkish delegation, under İsmet İnönü, though

${ }^{14}$ Melek Fırat, “1923-1939 Yunanistan'la İlişkiler”, Baskın Oran (ed.), Türk Dış Politikeası Kurtulus Savaşından Bugüne Olgular, Belgeler, Yorumlar, Cilt I, İstanbul, İletişim Yayınları, 2001, p. 341.

15 Macar, Cumburiyet Döneminde..., pp. 65-83.

${ }^{16}$ For the details and importance of the Lausanne Peace Treaty see, Baskin Oran, "1919-1923 Kurtuluș Yılları Lausanne Barıș Antlaşması", Baskın Oran (ed.), Türk Dış Politikası Kurtuluş Savaşından Bugüne Olgular, Belgeler, Yorumlar, Cilt I, İstanbul, İletişim Yayınları, 2001, pp. 215-238; Çă̆r1 Erhan (ed.), Yaşayan Lozan, Ankara, T.C. Kültür ve Turizm Bakanlığı Yayınları, 2003. 
recognizing the age-long status of the Patriarchate, formally demanded its expulsion from Turkey, as a condition for the exemption of Istanbul from the compulsory exchange of population between Turkey and Greece. ${ }^{17}$ According to the Turkish delegation's view, the Patriarchate should be excluded from the Turkish soil, because it was acting as a "political institution", referring to its activities during the Turkish Independence War. ${ }^{18}$ In addition, its exclusion from Turkish soils was obligatory for the modern Republic of Turkey which was established upon democratic values and which had separated the caliphate from state issues. Thus the privileges given to nonMuslims during the Ottoman era were ended and the religious leaders were to be affiliated only to "spiritual" issues. Therefore according to this, the Patriarchate which was always a political institution, with the abolishment of its political privileges had no reason of existence in Turkey. ${ }^{19}$

The request of the Turkish delegation was strongly opposed by all the Allies. The solution that was accepted was such as: the Patriarchate would stay in Istanbul, but its competences would be strictly only in religious affairs. ${ }^{20}$ Thereby, with this unwritten agreement in Lausanne, the old non-religious authorities and privileges of the Patriarchate were terminated and it remained in Istanbul as a religious institution of the Greek Minority. In a way the legal basis of the Patriarchate was left to Turkish law. ${ }^{21}$

Towards to the end and after the end of the World War II, both Turkey and Greece were facing the Soviet threat. In its struggle with the Soviet Union, which mainly consisted of

\footnotetext{
${ }^{17}$ Funda Keskin, “Türk ve Rum Nüfus Mübadelesi Sözleşmesi”, Yaşayan Lozan, ed. Çağnı Erhan, Ankara, T.C. Kültür ve Turizm Bakanlığı Yayınları, 2003, p. 783.

18 A. Suat Bilge, "The Fener Greek Patriarchate", Perceptions Journal of International Affairs, Vol. III, No. 1 (March-May 1998), p. 2.

${ }^{19}$ Keskin, “Türk ve Rum...”, p. 785.

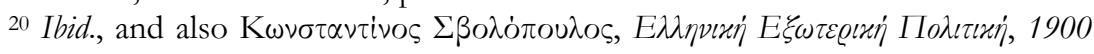

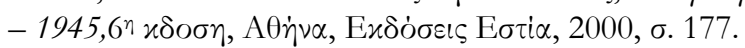

${ }^{21}$ Keskin, “Türk ve Rum...”, p. 786.
} 
Orthodox peoples, the United States used the Patriarchate as a tool of its own world policy. During the Second World War, the Soviet leader Stalin in order to keep together the Russian people had used religious components. After the end of the war, Stalin by emphasizing the religious link among the Orthodox people in the Balkans and in the Middle East reflected the Soviet interest to these regions. Therefore the Soviet leader by doubting the status of the Patriarchate (according to Stalin the Greek Orthodox Patriarchate was not able to function properly), turned the attention of the United States towards it at the early years of the Cold War. ${ }^{22}$

In addition to Soviet interest towards the Orthodox world, the supportive statements of the Patriarch Maksimos V in favor of the communist forces at the ongoing civil war in Greece, led to the intervention of the United States. Patriarch Maksimos V with the persuasive influence of Greece was forced to resign. After bargaining and discussions among US, Greece and Turkey, in November 1948, Athinagoras, the Archbishop of North and South America, was elected Patriarch. The striking point at the election of Athinagoras as Patriarch was not just the intervention of the United States but also the fact that for the first time a Patriarch who was not a Turkish citizen was elected as Patriarch. ${ }^{23}$ The new Patriarch came to Turkey on US President Truman's private airplane on 26 January 1949 and Turkish President İsmet İnönü received Athinagoras at his residence. As it is obvious during the first years of the Cold War there was an increased cooperation between Turkey and Greece with the support of the United States. Therefore the election of Athinagoras demonstrates the

${ }^{22}$ Melek Fırat, “1945-1960 Yunanistan’la İlişkiler”, Baskın Oran (ed.), Türk Dış Politikeası Kurtulus Savaşından Bugüne Olgular, Belgeler, Yorumlar, Cilt I, İstanbul, İletişim Yayınları, 2001, p. 584.

23 Obligations contained in the Regulations of the Greek Patriarchate, dated 1862, stipulated that candidates for Patriarch should be Ottoman citizens. As reflected in the official communication from the Governor's Office of Istanbul, dated 1923, candidates for Patriarch should be Turkish citizens. Athinagoras gained Turkish citizenship after his election as Patriarch. For details regarding the election of Athinagoras see Macar, Cumburiyet Döneminde..., p. 123-124. 
international aspect of the Greek Orthodox Patriarchate, despite the Turkish state's perception of the Patriarchate as a Turkish institution and subject of Turkish law.

On the other hand, the emergence of the Cyprus issue and Events of September 6-7 marked the derogation in Turkish-Greek relations and their policies towards their minorities. It can be said that the breaking point between Turkey and Greece was the Turkish military intervention to Cyprus in 1974. Since then, the issue of the Greek Orthodox Patriarchate and the Heybeliada Theological School, together with many other topics related with the Greek Minority of Istanbul and Turkish Minority of Western Thrace ${ }^{24}$, whether right or wrong, became subjects of "reciprocity" between Turkey and Greece, subjects of "national interest" and subjects of nationalistic feelings. In addition the radical demise of the Greek population living in Istanbul changed the balance established in Lausanne. ${ }^{25}$

The last two decades of the Cold War are characterized as "secluded years" 26 for the Patriarchate under the rule of Patriarch Dimitrios I. There are mainly two reasons for such a characterization. Firstly, since 1974 Turkish-Greek relations were uneasy and there was an increased possibility of hot confrontation. Secondly, due to the détente era in international politics the attention was turned towards the communist world. However, with the end of the Cold War which coincides with the enthronement of Vartholomeos I (Dimitrios Arhondonis, his

\footnotetext{
${ }^{24}$ For details regarding the Turkish Minority of Western Thrace see, Baskin Oran, Türk Yunan Ilisskilerinde Batı Trakya Sorunu, 2rd ed., Bilgi Yayınevi, Ankara,

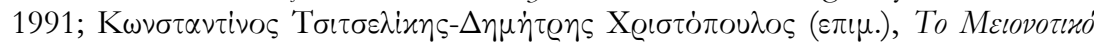

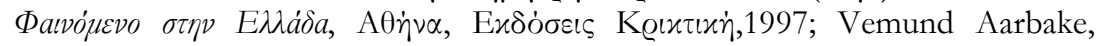
Muslim Minority of Greek Thrace, (Unpublished Ph.D. Thesis), Bergen University, 2000 .

${ }^{25}$ According to a recent publication the number of Greeks living in Istanbul is around 2000. Elçin Macar-Mehmet Ali Gökaçt1, Discussions and Recommendations on the Future of the Halki Seminary, Istanbul, TESEV Publications, April 2009, p. 19.

${ }^{26}$ Macar, Cumburiyet Döneminde..., p. 225.
} 
secular birth name) as Patriarch (2 November 1991), the status of the Greek Orthodox Patriarchate regained importance and attention. This turn of attention towards the Patriarchate is due to different international factors.

One factor is Russia which through the Russian Orthodox Church began to challenge the "ecumenical" status of the Greek Orthodox Patriarchate. The aim of Russia trough this policy is interpreted as a move to have a control over the Eastern Orthodox countries via the Russian Orthodox Church. ${ }^{27}$ The United States responded to this challenge by putting pressure on Turkey ${ }^{28}$ to solve the problems of the Greek Orthodox Church and to recognize its "ecumenical" status. Therefore though the Cold War came to an end, the old competition between the United States and Russia was transferred into another areas and the Greek Orthodox Church was and is one these areas of new influence and politics. Another factor is related with the activities of the Patriarch Varthomoleos I. Environmental meetings ${ }^{29}$ organized by the Patriarchate since 1990 and the official visits of the Patriarch to mainly the United States and many European countries increased his popularity and thus Greek Orthodox Patriarchate's.

\footnotetext{
27 The point of conflict between the Greek Orthodox Patriarchate and the Russian Orthodox Church arose soon after the end of the Cold War on jurisdiction rights over the Ukrainian and Estonian Orthodox Churches. For details see İlber Ortaylı, "Ukrayna Kilisesindeki Gelişmeler", Avrasya Etüdleri, Vol. 3, No. 3 (Sonbahar 1996), p. 54; and Anar Somuncuoğlu, "Roma Katolik Kilisesi ve Fener Rum Patrikhanesi'nin Eski Sovyet Alanındaki Faaliyetleri", Stratejik Analiz, Vol. 3, No. 28 (Ağustos 2002), p. 63.

${ }^{28}$ Macar, Cumburiyet Döneminde..., p. 241.

${ }_{29}$ Patriarch Vartholomeos because of his efforts and works on environmental issues is named as "the Green Patriarch", John Chryssavgis, "Ecumenical Patriarch Bartholomew: insights into an Orthodox Christian worldview," in The International Journal of Environmental Studies 64, 1 (2007) 9-18. For the details of these environmental meetings and their effects upon the increased popularity of the Patriarchate see, Prodromos Yannas, "The Soft Power of the Ecumenical Patriarchate", Mediterranean Quarterly, Vol. 20, No. 1 (Winter 2009), pp. 77-93 and Religion, Science and the Environment, <http://wmw.rsesymposia.org/>, (access date: 25 February 2010).
} 


\section{A Brief History of the Heybeliada Theological School}

The issue of reopening Heybeliada Theological School in Turkey has been and is being discussed for more than three decades. The Heybeliada Theological School which is located on the island of Heybeliada in the Marmara Sea, was established on the Umut Tepesi (Hill of Hop) in the Monastery of the Holy Trinity on October 1st 1844. It was found on a supranational base, to educate clergymen, providing homogeneity in theological terms, in order to maintain religious unity amongst the Orthodox communities that had already formed independent nation-states beginning from the $19^{\text {th }}$ century. Since its establishment around 900 students have graduated from the school, including the current Patriarch Varhtolomeos I. ${ }^{30}$

From the date of its establishment, the school has passed through a number of organizations. Initially, between 1844 and 1899 the school operated with four high school grades and three theological grades. Between 1899 and 1923 the high school grades were discontinued and the school functioned as an academy of five grades. The following period, between 1923 and 1951 the school reactivated the high school grades as originally established in 1844. And finally in 1951 the educational program was again modified to consist of three high school grades and four theological grades and this arrangement continued until 1971 when the school was closed after passage of a law that prohibited operation of privately owned schools of higher education in Turkey. The problem arose upon this because there was no university that the higher education division of the school, the Theological Department, could be transferred and therefore it was closed. ${ }^{31}$

\footnotetext{
30 Macar, Cumburiyet Döneminde..., pp. 288-298.

31 The legal basis of the closure of the Theological School is based on the Constitutional Court's cancellation of some articles of Law no. 625, concerning Private Institutions of Higher Education. According to this, all private higher education institutions were to be transferred to official higher education foundations, meaning to universities, see Melek Firat, “1990-2001 Yunanistan'la
} 
On the other hand, the high school division of the school, holding the statute of a minority school, continued its education facilities with the name of "Heybeliada Özel Rum Erkek Lisesi" for a while. Due to the huge decrease of the Greek minority in Istanbul after 1974, the number of students also decreased and in 1984 the high school was closed by the Patriarchate itself. ${ }^{32}$ Following the closure of the school, there have been made various attempts to allow the school to operate under a state university, like other private higher schools. The solution of opening the closed theology department of the school as a department providing education on Orthodox religion in one of the Theology Faculties, proposed in 1971 by the Ankara University Senate, was not accepted by the Patriarchate. ${ }^{33}$

The period following the Turkish military intervention to Cyprus in 1974, the Patriarchate, as mentioned above due to rapid emigration of the Greek minority living in Istanbul, began to have hard time on finding persons willing to be clergymen. Thus the need for clergymen became one of the Patriarchate's most obvious problems. On April 4 1996 Patriarch Vartholomeos I, wrote a letter to Prime Minister Mesut Yllmaz, stating that the Patriarchate needed clergymen and that candidates had been sent abroad for their education following the closure of the school. Vartholomeos at his letter mentioned that this solution this did not yield expected results and led to new problems, thus he requested the school to be reopened. ${ }^{34}$ However, no step was taken by the Turkish state upon this request of the Patriarch. Additionally at the same period of time, the discussions regarding Heybeliada Theological School

İlişkiler”, Baskın Oran (ed.), Türk Dış Politikeası Kurtuluş Savaşından Bugüne Olgular, Belgeler, Yorumlar, Cilt II, İstanbul, İletişim Yayınları, 2001, p. 451.

32 Idem.

33 Nimet Özbek Hadımoğlu, "Minority Schools, Foreign and International Schools in the New Law on Private Educational Institutions", Ankara Law Review, Vol. 5, No. 1 (Summer 2008), p. 76.

${ }^{34}$ Macar, Cumburiyet Döneminde, pp. 296-297. 
became clearly correlated with the educational problems of the Turkish Minority of Western Thrace. ${ }^{35}$

Nonetheless, the discussions about reopening the school since 1990's began to occupy the agenda of successive Turkish governments. In the meantime, comments and criticisms made by US Presidents and many Western and European countries regarding this subject signed the reality that Heybeliada Theological School was to become an important foreign policy issue. ${ }^{36}$ Bearing in mind the international dimensions of the issue, in 1999, prior the EU Helsinki Summit where Turkey was given candidacy status, a solution was proposed by the Turkish Higher Education Board (Yüksek Ögretim Kurulu -YÖK).

According to the Turkish media, the request was taken to the National Security Council upon the recommendation of the Ministry of Foreign Affairs. It was noted that reopening of the school would be beneficial to Turkey's foreign affairs and therefore a solution was sought. ${ }^{37}$ Thus, upon the request of the Directorate of Security Affairs of the Prime Minister, the Higher Education Council decided in its meeting on September 14th 1999 to establish the Department of World Religions and Cultures within the body of the Theology Faculty of Istanbul University. The duty to establish the department was given to Zekeriya Beyaz, Theology Professor. However, the interest shown to such a formulation was little and as a result the said matter was left in an abeyance. $^{38}$

Today, the issues raised and sought for solution by the Orthodox Greek Patriarchate can be summed up such as, due to the rapid decrease of the Greek community of Istanbul the issue of the election of patriarchs and the status of foreign clerics serving at the Patriarchate, the "ecumenical" title of the

35 Ibid., p. 297.

36 Firat, “1990-2001 Yunanistan'la İlişkiler”, p. 451.

${ }^{37}$ Hürriyet, 28 November 1997.

38 Macar-Gökaçt1, Discussions..., p. 13 and Hürriyet, 20 December 1999. 
Patriarchate which is not recognized by the Turkish state, the reopening of the Heybeliada Theological School, the problems in Greek Minority education, the loss and confiscation of properties, the Law on Minority Foundation and complaints about having "no dialogue" with the Turkish state. ${ }^{39}$ But the two basic demands of the Patriarchate, the reopening of the Theological School and its non-recognized "ecumenical" status by Turkey are the most discussed ones and according to Elçin Macar the Patriarchate has urgent expectations on solution of these issues. ${ }^{40}$

\section{The Reflection of the Issues among Turkish Intellectuals}

As mentioned before, with the end of the Cold War, in Turkey, the so called "taboo" issues, such as the Patriarchate and Heybeliada Theological School, began to be discussed openly among Turkish intellectuals. Though Turkish public opinion is far from having reached a consensus in these specific issues, for years, the Patriarchate has been the favorite target of the nationalist/ultra-nationalist and/or fundamentalist/religious media and interest groups in Turkey. This nationalistic tendency in Turkish public opinion paradoxically reached to its zenith point in 1990's because, for years issues regarding ethnic and religious minorities were either disregarded or perceived as an external threat against the solidarity of the country.

Therefore as discussed above, the activities and increased popularity of Patriarch Vartholomeos I, who uses the "ecumenical" title which is not accepted by the Turkish state and is perceived as a threat, increased this negative tendency. Additionally the problems of the Turkish Minority of Western

\footnotetext{
39 For a detailed list and arguments raised by the Patriarchate see, The Ecumenical Patriarchate, Memorandum, 05 May 2006,

<bttp://wnw.archons.org/pdf/issues/E.P._Problems_faced.pdf>, (access date: 20 December 2009).

${ }^{40}$ Macar, Cumburiyet Döneminde..., p. 261.
} 
Thrace at this period $^{41}$ began to take place in Turkish and international media creating reaction against Greece and therefore against the Patriarchate. However, the intensified efforts of Turkey in the last decade to become a member of the EU, the normalization of Turkish-Greek relations especially since 1999 EU's Helsinki Summit and lastly JDP government's valiant step such as the "democratic opening" towards the Kurdish origin Turkish citizens, inevitably put the Patriarchate once again on the agenda of the Turkish government and researchers, academicians, intellectuals, journalists.

By time the traditional general acceptance of these institutions as Turkish and the Turkish state's and Turkish governments' reluctance began to be questioned by a part of Turkish intellectuals. Thus it can be said that not all Turkish skeptics and the whole of the Turkish public opinion have the same understanding upon the said issues. As it will be discussed below, there is a group of intellectuals that supports the recognition of the "ecumenical" title of the Patriarchate and the reopening of the theological School. On the other hand there is also an opponent group that denies the "ecumenicity" of the Patriarchate and its recognition by the Turkish state and correlates the reopening of the Heybeliada Theological School with the "reciprocity" understanding between Turkey and Greece. Therefore before analyzing JDP government's policy is better to see the contrasting point of views in Turkey.

According to the views of the supporting group the recognition of the Patriarchate as "ecumenical" is of great importance to Turkey. First of all, the recognition of the "ecumenicity" of the Patriarchate is an issue related with Turkey's obligations protecting minority rights, religious freedoms and therefore a matter of democratization. In such a critical period as the commencement of Turkey's EU accession negotiations,

\footnotetext{
${ }^{41}$ Melek Firat argues that Turkish minority of the Western Thrace have begun to raise their problems more vocally along with the end of the Cold War. Firat, “1990-2001 Yunanistan’la İlisskiler”, p. 440.
} 
recognizing the Patriarch as the universal spiritual center for all Orthodox Christians will yield great benefits to the already very negative Turkish image in Europe. It is also believed that, by recognition of the ecumenical title, Turkey would show the change in its minority policy, which has frequently attracted criticism from the Europe and thus Turkish foreign policy can benefit from this. ${ }^{42}$ Additionally whether the Patriarchate is "ecumenical" or not is an issue that concerns Christian teaching and according to Islamic law Muslims do not have the right to intervene to such an issue. ${ }^{43}$ However, the other camp that is against recognizing the Patriarchate as "ecumenical" seems to be quite unimpressed with the arguments of the supporting group and view these arguments as no more than wishful thinking.

As a response to the arguments of the supporting group, the opposing group claims that the Patriarchate is on Turkish soil and therefore it is a Turkish institution subject to Turkish legal system. The Republic of Turkey does not have any legal obligations whatsoever to recognize the ecumenical status of the Patriarchate because this status has been given to it during the Ottoman Empire period. With the abolishment of the caliphate and the establishment of the Turkish Republic, the privileges of every religious institution were also abolished. According to the unwritten agreement at the Lausanne Conference, the continuing existence of the Patriarchate in Istanbul is only possible if it does not get involved in secular affairs. Therefore its recognition as "ecumenical" will make it a political institution. The common fear is that, if the Turkish government agrees to call the Patriarchate as

\footnotetext{
42 Macar, Cumburiyet Döneminde..., p. 271 and see also Fikri Akyüz, at his article on 20 November 2006 Yeni Şafak daily with the title "Nutuk'taki beş vatan haini kimdi?" criticizes the opinions of the other camp, namely the "against group" especially their "reciprocity" argument,

<http:/ /yenisafak.com.tr/yazarlar/?t=20.11.2006 \&y=FikriAkyuz>, (access date: 18 August 2010) and see also Hüseyin Hatemi, "Mütekabiliyet", Yeni Şafak, 24 February 2008,

<bttp:/ /yenisafak.com.tr/Yaaarlar/ ?t=24.02.2008\&y=HuseyinHatemi>, $\quad$ (access date: 20 August 2010).

${ }^{43}$ Macar, Cumburiyet Döneminde..., p. 272.
} 
"ecumenical", this will mean as a breach of the laws and regulations that prevent the religious institutions from developing into political actors. This, on the medium run, is thought to unleash a series of turmoil within other religious institutions in Turkey, tremendously harming Turkey's secular state tradition. While the Patriarch is using the title "ecumenical", this group, as well as the Turkish state, insists on calling him "Phanar Greek Patriarch" (Fener Rum Patriğ ), hence highlighting the fact that the Patriarch is a Turkish national and the leader of the Patriarchate which is a Turkish institution. Also according to the views of the opposing group, the Patriarchate cannot be thought separately from the Turkish Minority of the Western Thrace. ${ }^{44}$ Thus they are advocating the confirmed "reciprocity" understanding.

Regarding the reopening of the Heybeliada Theological School, a part of the supporting group defends that the opening of the Theological School and supporting the Patriarchate at home and abroad. This could be approached as national interest as it would be advantageous to Turkey in various ways, including aspects of foreign policy and the EU membership process. ${ }^{45}$ As it is understood this view is related with strengthening the hand of Turkish foreign policy bureaucrats. Another part of the supporting

\footnotetext{
${ }^{44}$ For an example of the views of the opposing group see Şükrü Elekdağ, "Patrikhane'nin Statüsü”, Milliyet, 03 December 1995. Also see Emruhan Yalçın, Atatürk Türkiye'sinde Ekümenik Ortodoks Patrikhanesi ve Bizans Projesi, Ankara, Siyasal Kitabevi, 2008.

45 For example Mehmet Ali Birand on 22 May 2009 at the Turkish daily Milliyet wrote that: "Turkey not only unfairly quarrels with its own bread and butter but also transgresses international treaties. We are falling to the trap of parochialism which defends the paranoia that "a new Vatican will be established and the Greeks will partite Turkey". We are becoming a country pressuring Orthodoxy and opposing to religious freedoms. We are quarrelling with our own bread and butter, because by preventing the education of religious leaders in our country, who will command the Orthodox world, someday we will have to leave this privilege to the Russian Church. We are quarrelling with our own bread and butter, because we are excluding the religious leader Vartolomeos who is our most important ally". "Türkiye Ruhban Okulu Firsatını Kaçırıyor", $<$ bttp:/ / www.milliyet.com.tr/ default.aspx?aType $=$ YazarDetay\& ArticleID $=1097443>$, (access date: 18 August 2010).
} 
group, as on the "ecumenical" title of the Patriarchate, evaluates this issue within the frame of Turkey's democratization efforts and obligations towards its minorities. ${ }^{46}$

The third part composing the supporting group can be defined as the conservative or "Islamic Group." There are two reasons this group is not opposed to the opening of the school. The first one is that this group starts with notions of Islamic history and practices and argues that Islam confers members of other religions with the right to live as required by their own standards. The effect of the Ottoman's millet system over such an understanding is quite large. Additionally, there is an expectation that the opening of the Theological School would set a precedent and would therefore be helpful in removing "restrictions" believed to exist on Islamic groups. ${ }^{47}$ This approach is mainly related with Turkey's much debated secularism understanding. However, a smaller segment of the "Islamic Group" which has nationalistic leanings is against to such an approach. ${ }^{48}$

In response to the above arguments the opposing group argues that the reopening of the Heybeliada Theological School according to Patriarchate's wishes, which is to function as prior 1971, meaning to be under the auspices of the Patriarchate and not of the Ministry of National Education, cannot be accepted. Such an action could lead also to the demand of Islamic groups open religious schools and thus could permanently damage the secular

\footnotetext{
46 Macar-Gökaçtı, Discussions..., p. 22.

47 On the other hand Ali Bulaç, at his article on Turkish Daily Zaman on 4 October 2006 argued that "keeping meaninglessly closed the Theological School by referring to the baseless "reciprocity" principle has no relevance with the Ottoman model and Islam religion. Islam religion hasn't such restrictions and didn't had in history. Therefore, it is an obligatory step to take under cover the basic rights and freedoms on non-Muslims like other citizens (Muslims)", "Dini Şiddetin Akli Temeli",

< bttp:/ / wnw.zaman.com.tr/ yazar.do?yazino $=432346 \&$ \&eyfield $=64696 \mathrm{E} 6920$ C59F69 64646574696E20616B6C692074656D656C69>, (access date: 18 August 2010) and Sabah, 19 August 2003.

48 Macar-Gökaçt1, Discussions..., p. 21.
} 
system. $^{49}$ A more radical part of the opposing group argues that the Theological School is "the Military College of the Patriarchate and even of the Megali Idea $\left(M \varepsilon \gamma a \dot{\lambda} \eta I \delta \varepsilon^{\prime} a\right)^{50}$ and Turkey cannot therefore be expected to allow Greece to educate clergymen who will support such imperialist ideology". ${ }^{51}$ Finally, the common denominator of the "against group" is related again with the understanding of "reciprocity", a bargaining tool towards Greece in order to help solve the problems of the Western Thrace Turks.

\section{JDP Government's Position: Is Anything New?}

Bearing in mind the historical background of the subject matters and the discussions in Turkey is time to analyze JDP government's policy. When JDP government took office on 2002, the discussions of reopening Heybeliada Theological School repeatedly returned to the international and domestic political agenda of Turkey. It was believed that JDP, since it is quite sensitive on issues regarding religious freedoms, would seriously formulate a solution and reopen Heybeliada Theological School. As it will be discussed below, JDP government's policy towards the reopening of the school has remained on verbal basis like predecessor Turkish governments.

\footnotetext{
${ }^{49}$ Emruhan Yalçın, "Heybeliada Ruhban Okulu'nun Yeniden Açılması”, Ankara Üniversitesi Türk İnkılâp Taribi Enstitüsü Atatürk Yolu Dergisi, No. 41 (May1s 2008), p. 157; Emre Özyılmaz, Heybeliada Rubban Okulu, Ankara, Tamga Yayınları, 2000, p. 139.

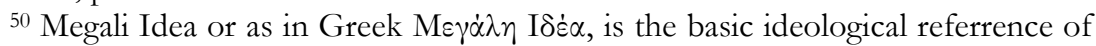

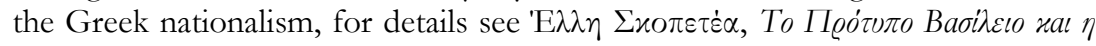

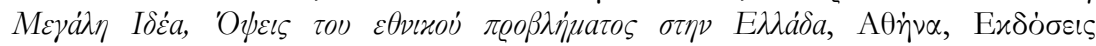

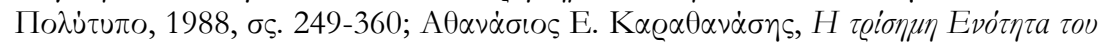

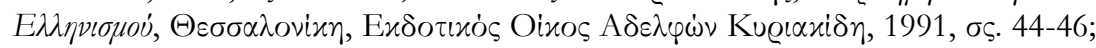

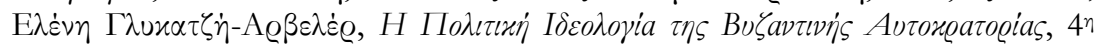

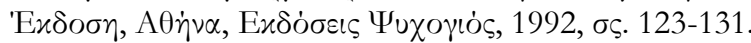

${ }^{51}$ Macar-Gökaçt1, Discussions..., p. 21. For an example of this view see Ahmet Hikmet Eroğlu, "Heybeliada Dayatması Niye",

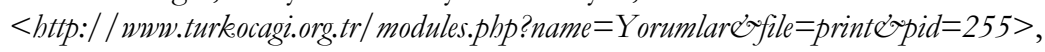
(access date: 15 August 2010).
} 
As pointed out previously, when JDP won the elections and formed a single party government first in 2002 and then in 2007, there was a belief that problematic and chronic issues such as religious rights and freedoms related not only with Muslims but also related with non-Muslims can find remedy due to JDP's proIslamic tendencies and due to its sensitive leaning especially on religious affairs and freedoms. It was also believed that JDP as holding the majority of the Turkish Parliament and as being a single party government, could more easily change the confirmed policy and understanding of "reciprocity" on issues related with the Patriarchate and Heybeliada Theological School. However the developments that are taking place below present no change from the traditional policies and approaches regarding our subject matters.

The first exam of the JDP government regarding the "ecumenical" title of the Patriarchate took place on 3 December 2003, prior to the dinner arranged by the council of the representatives of the Patriarchate for Eric Edelman, the US ambassador to Turkey. The source of the crisis was the title "Ecumenical" written on the invitation cards for the Patriarch Vartholomeos I, who was the honorary patron of the dinner that would be held at the residence of Ambassador Edelman. Most of the Turkish officials, who also received the invitation to the dinner, have reacted to this and decided not to attend. In addition this event created a mini crisis between Turkey and the United States. As a consequence of the escalating tension, the spokesman for the US embassy, Josef Pennington has issued a press release, concluding that "...many of the Americans and Europeans as well as people around the world, view the Patriarchate as ecumenical. The United States has always used this title for the Patriarch and there is nothing new in our position in this issue. People, who do not wish to come, may not attend the dinner". ${ }^{52}$ As it is apparent from this instance the JDP government's attitude on the "ecumenical" status of the Patriarchate is the same as the

${ }^{52}$ Hürriyet, 4 December 2003. 
predecessor Turkish governments and in compliance with state policy.

Another example upon JDP's attitude on the "ecumenical" title of the Patriarchate came from the Deputy President of the governing Justice and Development Party Şaban Dişli who, sitting on the same panel with Patriarch Vartholomeos I for the 9th Dialogue meeting of the European People's Party with the Orthodox Church, said that "The Patriarch is the spiritual leader of the Orthodox of Fener, his role is constrained and the Patriarchate is a Turkish institution that concerns only Turkish citizens". ${ }^{53}$ Quite recently, the ecumenical claim of the Patriarchate was put to rest by the Turkish judiciary. The Court of Cassation, in rejecting an appeal brought by members of the Synod of the Patriarchate against a decision of a local court surrounding the case of priest Konstantin Kostoff, reasoned that the Patriarchate "bears only religious powers as the church of the Greek minority in Turkey" and affirmed that "there is no legal claim that the Patriarchate is Ecumenical". ${ }^{4}$

Regarding Heybeliada Theological, the first official meeting took place on 08 August 2003, almost a year after the JDP government's coming on power. Patriarch Vartholomeos I together with the lawyers of the Patriarchate had a meeting with the Foreign Minister Abdullah Gül. At this meeting Patriarch expressed his demand on reopening the Theological School. On behalf of the JDP government then Minister of Foreign Affairs, today's President of the Republic, Gül pointed out that their wish is that all Turkish citizens should live, no matter their ethnic origin or religious belief, in peace and harmony. Minister Gül also added that JDP government is working to find a solution upon the reopening of the Theological School and that Greece should also make an opening related with the Theological School, towards the Turkish Minority of Western Thrace. ${ }^{55}$

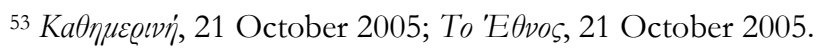

54 Sabah, 26 June 2007.

55 Milliyet, 08 August 2003.
} 
On the 28th of August of the same year Prime Minister Erdoğan also met with Patriarch Vartholomeos I and said that he understands the legal and political problems the Patriarchate is facing. Vartholomeos, at this meeting also expressed the demand of reopening the Theological School. The answer of Erdoğan to this demand was as "We will think, we will try to find a solution. Of course we are waiting also a step from Greece towards the Turkish Minority in Western Thrace". In addition he expressed that besides Western Thrace that he wants a mosque to be opened in Athens. ${ }^{56}$ Parallel statements, that the reopening of the Heybeliada Theological School is correlated with the Turkish Minority of Western Thrace, were made also by the Turkish Minister of National Education Hüseyin Çelik on November 2003 in Athens at a meeting of Council of Europe where he met with Petros Efthimiou, Greek Minister of Education and Religious Affairs. On the other hand according to the response of the Greek Minister, the issue of the Theological School has no relation with the "reciprocity" understanding and it should be solved within the European Union framework. ${ }^{57}$

On the occasion for year-long celebrations for the 550th anniversary of the Greek School in Fener in 2004, Turkey's Education Minister Hüseyin Çelik attended ceremonies with the Greek Education Minister at the time Petros Efthimiou. At this ceremony Minister Çelik pointed out that he didn't see any reason why it couldn't be opened. ${ }^{58}$ Hüseyin Çelik repeated his claim in Sabah newspaper interview on August 2004. At that time he pointed out that if an Islamic religious faculty with a Turkish Muslim in charge of it could be built in the center of Rotterdam in the Netherlands, why couldn't the school be reopened. ${ }^{59}$ However

\footnotetext{
${ }^{56}$ Milliyet, 27 September 2003.

57 Milliyet, 11 November 2003.

${ }^{58}$ Gül Demir and Niki Gamm, "The never ending story of Halki Theological Seminary reopening", Hurriyet DailyNews.com, 18 April 2009, <bttp://wnw.burriyet.com.tr/english/domestic/11457790.asp>, (access date: 15 March 2010).

${ }^{59}$ Idem.
} 
though the discussions continue even today nothing actual has been done yet. Nonetheless the international expectations and optimism continued at this period of time. ${ }^{60}$

From 2004 up until recently the subject matters were put on the back burner of the JDP government. Though the JDP government followed a low profile approach to these issues from this period of time, international "pressures" and "recommendations" especially by the EU have increased. For example in the last five Progress Reports of Turkey prepared by the European Commission there is always a reference to the non recognition of the "ecumenical" status of the Greek Orthodox Patriarchate by Turkey as a ban and criticism for the continued closure of the Heybeliada Theological School. ${ }^{61}$

But the matter of Heybeliada Theological School took place also at the meeting of Turkish Prime Minister Erdoğan with the US President Barrack Obama, at his official visit to the United States on December 2009. US President, as his predecessors once again expressed the demand of reopening the Theological School. Erdoğan regarding this demand said that there is an ongoing study

60 Ulrich Pick, “Türkiye Hristiyanları'nın AB Beklentisi”, Deutsche Welle, (access date: 12 August 2004,

$<$ http:/ / mnw.istanbulrumazinligi.com / index.php? $m=$ art\& $c=807 \& n=510>, \quad$ (access date: 19 August 2010).

${ }^{61}$ See Turkey 2005 Progress Report, European Commision, Brussels, 09 November 2005, p. 31, <http://www.mfa.gov.tr/data/AB/2005_progress.PDF>, (access date: 24.08.2010); Turkey 2006 Progress Report, Commission of the European Communities, Brussels, 08 November 2006, p. 79,

<http:// mmw.mfa.gov.tr/data/AB/Ilerlemeraporu_en_8Kasim2006.pdf>, (access date: 24 August 2010); Turkey 2007 Progress Report, Commission of the European Communities, Brussels, 06 November 2007, p. 18,

< bttp:// mmw.mfa.gov.tr/data/AB/2007IlerlemeRaporu_ing.pdf>, (access date: 24 August 2010); Turkey 2008 Progress Report, Commission of the European Communities, Brussels, 05 November 2008, p. 20, <bttp:// www.mfa.gov.tr/data/ AB/ILLERLEME\%20RAPORU\%202008\%20NIH AI.PDF>, (access date: 24 August 2010); Turkey Progress Report 2009, Commission of the European Communities, Brussels, 14 October 2009, p. 22, <https:// wnw.mfa.gov.tr/data/AB/2009_Ilerleme_Raporu_Ingilizce.pdf>, (access date: 24 August 2010). 
of the Ministry of Education. On the other hand referring to the Lausanne Peace Treaty clauses, he expressed the problems of the Turkish Minority in Western Thrace and asked the contribution of the United States upon this subject. ${ }^{62}$

However, the response of Greece to the comments of the Turkish Prime Minister was given by the Greek Alternate Foreign Minister Dimitris Drutsas. On a telephonically interview Drutsas said: "Turkey, and any Turkish official, can of course say what they want, we said it clearly, we are not discussing issues regarding the Muslim minority - i.e., issues regarding Greek citizens - with third governments. It is a clear position, we've said so repeatedly. I think that Turkey can say whatever it wants to say, whenever it wants to, but Greece and the Greek people should listen to what the Greek government is saying - and it is crystal clear - on this issue". ${ }^{63}$

According to Turkish daily Milliyet, Prime Minister Recep Tayyip Erdoğan upon the question related with the Heybeliada Theological School, made the same comments and said that "the demands of the Western Thrace Turkish Minority from the Greek government should be also taken into consideration. The Greek government should also lean on and should solve the problems of the minority such as the election of religious leaders, unemployment and minority associations" ${ }^{\prime 4}$. Similar were the also the statements of the President of the Republic Abdullah Gül on a TV program which took place on the $4^{\text {th }}$ of January. The Turkish President of Republic on the reopening of the Theological School referred to the current situation of the Turkish Minority of Western Thrace and criticized Greece, an already EU member, for not taking action. ${ }^{65}$

\footnotetext{
${ }^{62}$ For details see Milliyet, 04 January 2010.

${ }^{63}$ For the details of this interview see Greek Ministry of Foreign Affairs, <bttp:// wnw.mfa.gr/wnw.mfa.gr/Articles/en-US/101209_NA1825.btm>, (access date: 10 February 2010).

${ }^{64}$ Milliyet, 04 January 2010.

${ }^{65}$ For the statements of Abdullah Gül Turkish President of Republic see, CNNTÜRK
} 
All these statements demonstrate that there is not a change of policy towards the recognition of the ecumenicity of the Patriarchate and also there is no change at the "reciprocity" understanding regarding the matter of reopening the Heybeliada Theological School. Thus these two issues will continue to be discussed and take place on the agenda of the Turkish governments and public opinion.

\section{Conclusion}

The JDP government since 2002 has created in a way a political stability in Turkey and made a number of important legal and constitutional changes necessary for meeting the requirements of the Copenhagen political criteria for joining the European Union. Also long aged and chronic problems of Turkey such as minority rights and freedoms, religious rights and freedoms become to be discussed more loudly. These developments created some momentum in Turkey, away from nationalistic and fundamentalist tendencies and actually showed that further democratization of state-society relations is indeed, for the good of Turkey and Turkish people. However current government's policies especially towards to the non-Muslim minorities living in Turkey continue to be at the same frameworks of traditional state policy.

The "ecumenical" title of the Greek Orthodox Patriarchate is not recognized. The discussions and formulations regarding the opening of the Heybeliada Theological School are linked with the reciprocity understanding established between Turkey and Greece at the Lausanne Peace Treaty. On the other hand, though in Turkish public opinion there are different points of view and though the perception of these institutions continues to be a matter interesting Turkish domestic politics, day by day the

<http:/ / www.cnnturk.com/2010/turkiye/01/04/gulden.cnn.turke.ozel.aciklamalar/ 557 957.0/index.htm〉, (access date: 15 February 2010). 
international dimension of these subject matters gains importance and consequently international pressure and criticisms increases. But mainly the most crucial paradox of JDP policies towards the Orthodox Patriarchate and Theological School lies down on the insistence of "reciprocity" understanding between Turkey and Greece and the acceptance of these institutions and issues as Turkish institutions, thus matters of Turkish politics. Whether JDP government will manage to transfer the discussion from verbal basis as it is now, to actions is quite doubtful. 